\title{
Serum thyrotropin and free thyroxine reference ranges as defined in a disease-free sample of French middle-aged adults
}

\author{
Carla Estaquio ${ }^{1,2}$, Pierre Valeix ${ }^{1,2}$, Laurence \\ Leenhardt ${ }^{3,4}$, Elizabeth Modigliani ${ }^{5}$, Marie- \\ Christine Boutron-Ruault ${ }^{6}$, Laurence Chérié- \\ Challine $^{3}$, Marguerite Legrand ${ }^{7}$, Serge \\ Hercberg $^{1,2}$ and Katia Castetbon ${ }^{1,2, *}$ \\ ${ }^{1}$ Unité de Surveillance et d'Epidémiologie \\ Nutritionnelle, Institut de Veille Sanitaire, Université \\ Paris 13, Cnam, Centre de Recherche en Nutrition \\ Humaine (CRNH) Ile-de-France, Bobigny, France \\ 2 UMR U557 INSERM, U1125 INRA, CNAM, Paris 13, \\ CRNH lle-de-France, Bobigny, France \\ ${ }^{3}$ Département Maladies Chroniques et \\ Traumatismes, Institut de Veille Sanitaire, \\ Saint-Maurice, France \\ ${ }^{4}$ Service de Médecine Nucléaire, Hôpital \\ Pitié-Salpêtrière, Paris, France \\ ${ }^{5}$ Service d'Endocrinologie et Médecine Interne, \\ Hôpital Avicenne, Bobigny, France \\ ${ }^{6}$ INSERM ERI 20, Institut Gustave Roussy, Villejuif, \\ France \\ ${ }^{7}$ Centre Médical de Forcilles, Attilly, France
}

\begin{abstract}
Background: The goal of this study was to provide reference ranges for thyrotropin (TSH) and free thyroxine $\left(\mathrm{fT}_{4}\right)$ based on data collected from a diseasefree sample of French middle-aged adults.

Methods: A total of 3218 subjects participating in the Supplémentation en Vitamines et Minéraux Antioxydants (SU.VI.MAX) study had measurements for TSH, $\mathrm{fT}_{4}$ and urinary iodine concentrations. Thyroid volume and structure were evaluated using standardized ultrasonography. We selected a disease-free sample which included 2338 subjects (1313 females aged 35-60 years and 1025 males aged $45-60$ years) with normal thyroid imaging, no previously reported thyroid disease or use of thyroid medication, and no risk factors for thyroid dysfunction. Distribution of TSH and $\mathrm{fT}_{4}$ was estimated in males and females.

Results: The median (central 95\% range) TSH serum concentrations for females were $1.79 \mathrm{mU} / \mathrm{L}$ (0.29-5.21 mU/L) for ages 35-44 years and $1.98 \mathrm{mU} / \mathrm{L}$ (0.27-6.94 mU/L) for ages $45-60$ years $(p<0.0001$, for age). The median (central $95 \%$ range) for males

*Corresponding author: Katia Castetbon, Unité de Surveillance et d'Epidémiologie Nutritionnelle, InVS-Paris 13-Cnam 74 rue Marcel Cachin, 93017 Bobigny Cedex, France

Phone: +33 (0)1 483873 73, Fax: +33 (0)1 48387374 ,

E-mail: katia.castetbon@univ-paris13.fr

Received April 15, 2009; accepted August 21, 2009

previously published online November 2, 2009
\end{abstract}

45-60-year-old was $1.63 \mathrm{mU} / \mathrm{L}(0.28-4.54 \mathrm{mU} / \mathrm{L})(\mathrm{p}<$ 0.0001 , for sex). Sex- and age-specific mean $\mathrm{fT}_{4}$ concentrations did not differ significantly $(p=0.06)$ between males and females and $(p=0.08)$ between female age groups. However, median $\mathrm{fT}_{4}$ concentrations between 45-60-year-old males and females differed $(p<0.001)$.

Conclusions: In middle-aged adults, the TSH distribution was associated with gender and, among females, with age. Stratification according to gender and age should be considered when TSH ranges are used in the diagnosis, treatment and monitoring of thyroid disease.

Clin Chem Lab Med 2009;47:1497-505.

Keywords: adults; free thyroxin; ranges; thyrotropin; ultrasonography.

\section{Introduction}

Epidemiological studies using biochemical thyroid function tests and/or clinical investigation have shown the prevalence of thyroid disorders to be about $10 \%$ in iodine-replete populations, occurring more frequently in females, and with aging in normal subjects (1). Clinical and biochemical diagnosis and follow-up, and the wide use of thyroid hormones yield high public-health-related costs. For example, in France, refunds for required hormonal thyroid function testing (10.2 million reimbursements) amounted to 137 million Euros in 2006 (2). The annual prescription volume for Levothyrox ${ }^{\circledR}$ (levothyroxine sodium) resulted in more than 18 million unit reimbursements (3). Reliable reference ranges, defined using apparently healthy individuals, must be established in order to adequately diagnose and manage thyroid dysfunction in the general population.

Measurement of serum thyrotropin (TSH) is the recommended initial screening tool for suspected thyroid disease. Daytime reference values for TSH in adults are in the range of $0.3-4.0 \mathrm{mU} / \mathrm{L}$, with a minimum between 0.2 and $0.5 \mathrm{mU} / \mathrm{L}$ and a maximum between 3.0 and $5.0 \mathrm{mU} / \mathrm{L}$ (4). The prevalence of endogenous subclinical thyroid disease varies with the TSH cut-off used to define them. Subclinical hyperthyroidism has been defined as a serum TSH concentration of $0.10-0.44 \mathrm{mU} / \mathrm{L}(5)$, and subclinical hypothyroidism as a serum TSH concentration of 4.5-10.0 mU/L (6). These criteria are sufficient when using an assay with adequate sensitivity. However, measurement of free thyroxine $\left(\mathrm{fT}_{4}\right)$ might also be recommended to confirm the diagnosis of subclinical 
hypothyroidism or hyperthyroidism, and to determine diagnostic strategies (7). Typical reference intervals for $\mathrm{fT}_{4}$ have usually been defined as $9-25 \mathrm{pmol} / \mathrm{L}$ (7.0-19.4 ng/L) (4).

Various criteria exist for defining an apparently healthy sample. Recent publications have used the National Academy of Clinical Biochemistry (NACB) consensus guidelines. These guidelines recommend selecting a reference sample by excluding subjects positive for autoantibodies against thyroid peroxidase (TPOAbs) and thyroglobulin (TgAbs), with visible or palpable goiter, and those taking any drugs except estrogens (8). Exclusion of subjects with a personal or family history of autoimmune disease, thyroid-related or not, is also recommended. Such rigorous selection would not lead to erroneous estimation of thyroid dysfunction. Indeed, exclusion of subjects with enlarged thyroid volume and diffuse hypoechogenicity of the thyroid on ultrasound examination could lead to better selection of individuals in the reference sample. Currently, there is no agreement concerning age- and gender-specific differences with regard to TSH and $\mathrm{fT}_{4}$ concentrations, despite reported variations (9-12). Diversity of current analytical methods and the specificity and sensitivity of enzyme immunoassays, as well as interpopulation variability (10-12), may explain the wide discrepancies between published reference range data $(13,14)$. Investigating and providing TSH reference values in various populations are also of interest, given risk factor variations in populations for body mass index (BMI) (15), alcohol intake (16), smoking habits (17) and iodine intake (18).

The objective of the present study was to determine serum TSH and $\mathrm{fT}_{4}$ ranges in French middle-aged adults included in the Supplémentation en Vitamines et Minéraux Antioxydants (SU.VI.MAX) study. These individuals were determined to be free of thyroid disease, with normal thyroid ultrasonography and not taking medication that would interfere with thyroid hormone testing.

\section{Materials and methods}

\section{Study population (1994-2002)}

The SU.VI.MAX study was a double-blind, placebocontrolled primary prevention trial evaluating the effect of daily antioxidant supplementation on the incidence of chronic disease (19). A total of 13,017 subjects recruited on a voluntary basis following a multimedia campaign, and living in mainland France, were included in 1994-1995 to be followed for 8 years. Due to the main objective of the trial, more female $(60 \%)$ than male participants were included. Females had a wider age range compared with males (35-60 years vs. 45-60 years). Written informed consent was obtained from all participants, and procedures were approved by the Regional Ethics Committee of Paris-Cochin [Comité consultatif de protection des personnes dans la recherche biomédicale (CCPPRB), $\mathrm{n}^{\circ} 706$ ] and the French Data Protection Authority [Commission National de I'Informatique et des Libertés (CNIL), n³34641].
Each subject underwent a yearly visit involving either biochemical sampling (at years 0, 2, 5 and 7) or clinical examination (at years 1, 3 and 7). Social and demographic characteristics were collected at inclusion by questionnaire. These included smoking habits (never, former or current smoker), marital status (whether subjects lived with a partner or not), education level ( $<13,13-14, \geq 15$ years), menopausal status and use of exogenous estrogens. Subjects were classified into one of four categories according to their self-reported occupation, or last occupation if they were retired or unemployed. Alcohol intake was estimated in grams of alcohol per day from a short validated semi-quantitative dietary questionnaire (20). Heavy alcohol intake was defined as daily self-reported consumption of $\geq 45 \mathrm{~g}$ ethanol/ day for males and $\geq 20 \mathrm{~g}$ for females (16).

\section{Laboratory methods (1994-1995)}

At baseline examination (October 1994-September 1995), a venous blood sample and morning urine sample were obtained from participants. Time of blood collection was between $7.30 \mathrm{am}$ and $11.00 \mathrm{am}$. Blood was left to clot at $4^{\circ} \mathrm{C}$ and then centrifuged. Serum was aliquoted and stored at $-25^{\circ} \mathrm{C}$ until analysis. Serum TSH and $\mathrm{fT}_{4}$ were measured in duplicate in random order with a MAGIA ${ }^{\circledR} 8000$ analyzer according to the manufacturer's instructions (Biotrol Diagnostic Company, Chennevières-lès-Louvres, France). TSH was measured using a one-step, two-site ultrasensitive enzyme-linked immunosorbent assay (ELISA) that utilized two monoclonal antibodies. The detection limit of the TSH assay was $0.02 \mathrm{mU} / \mathrm{L}$. The TSH standard 80/558 from the World Health Organization (WHO) was used as a calibrator for the TSH determination. $\mathrm{fT}_{4}$ was measured using a onestep competitive immunoassay. The lower limit of $\mathrm{fT}_{4}$ detection was $2 \mathrm{ng} / \mathrm{L}$ (conversion factor to $\mathrm{pmol} / \mathrm{L}: \mathrm{ng} / \mathrm{L} \times 1.3$ ). Reference ranges provided by the manufacturer were: $\mathrm{TSH}$, 0.12-6.1 mU/L; fT 4 , 7-17 ng/L (9.0-21.9 pmol/L). Within- and between-run coefficients of variation for $\mathrm{TSH}$ and $\mathrm{fT}_{4}$ were $<7.6 \%$ over a wide range of concentrations.

Urinary iodine concentration was measured in all participants in a random morning sample and urinary iodine concentrations were used as an index of iodine nutrition. The urinary iodine, after fully automated wet acid digestion (Technicon AutoAnalyzer II, Technicon Instruments Corporation, Tarrytown, NY, USA) was measured by means of a highly sensitive spectrophotometric procedure based on the Sandell-Kolthoff reaction. Urinary thiocyanate concentrations were measured using the same urine sample with an automated continuous-flow technique.

\section{Thyroid ultrasonography (1995-1996)}

Ultrasonography examination of the thyroid was performed in a randomly selected subsample of 3621 subjects (2160 females and 1461 males) after stratifying on gender, age and geographic location. Subjects were informed of ultrasonography examination on arrival at the screening site for the first biennial clinical examination. Examination was carried out in a mobile unit equipped with a high-frequency $7.5 \mathrm{MHz}$ linear array transducer (Sonoline ${ }^{\circledR}$ SI-400, Siemens, Erlangen, Germany). Studies were performed and interpreted by the same radiologist. Participants also answered a questionnaire concerning previous or present thyroid disease (total, subtotal thyroidectomy, lobectomy, nodules, goiter), previous or current use of thyroid medication (radioiodine, thyroid hormone supplementation, iodine-based or antithyroid drugs) and medications known to have an effect on thyroid hormone concentrations (glucocorticoids, interferons, dopa- 
mine agonists, antiepileptic agents), with the exception of estrogens. Ultrasonographic examinations were performed with the patient in a supine position and the neck hyperextended. Thyroid volume was estimated using the formula: volume of one lobe $(\mathrm{mL})=$ length $(\mathrm{cm}) \times$ width $(\mathrm{cm}) \times$ depth $(\mathrm{cm}) \times 0.479(21)$. Total thyroid volume $(\mathrm{mL})$ was obtained by computing the volume of both lobes. Nodules and cystic areas were included in thyroid volume determination, whereas the isthmus was not taken into account in volume calculations. This method has been proven to be very accurate (22). Goiter was defined as an enlarged thyroid volume exceeding $25 \mathrm{~mL}$ in males and $18 \mathrm{~mL}$ in females (23). Nodules and cysts included all focal abnormalities of the echo pattern that were $3 \mathrm{~mm}$ or more in diameter. Nodule frequency (1-3 nodules, paucinodularity, multinodularity) and components (solid and cystic) were classified qualitatively. Thyroid tissue density (echogenicity) which was slightly homogeneously more echoic than adjacent neck muscles was considered to be normal.

\section{Statistical analysis}

Statistical analyses were performed using Statistical Analysis System (SAS) software 8.2 (SAS Institute, Inc, Cary, NC, USA). Data were stratified according to gender and age in females (35-44 years and 45-60 years). The disease-free population was selected by successively excluding subjects with a family or personal history of thyroid disease (removal of thyroid lesions, nodule, goiter), subjects taking thyroid medication and those with risk factors for thyroid dysfunction: iodine contamination (urinary concentration $\geq 600$ $\mu \mathrm{g} / \mathrm{L}$ ), thiocyanate overload (urinary concentration $\geq 50$ $\mathrm{mg} / \mathrm{L}$ ) and pregnancy at the time of hormone analysis.

Serum TSH concentrations and log-transformed values were not normally distributed. TSH ranges were defined as the central $95 \%$ of the selected population comprising the 2.5th and 97.5th percentiles. Intervals for $\mathrm{fT}_{4}$ were defined as the 2.5th-97.5th percentiles following the exclusion of subjects with serum TSH outside the 2.5th-97.5th percentiles. Mann-Whitney $U$ and Student's t-tests were used to assess differences between groups when required.

\section{Results}

\section{Characterization of the disease-free population}

Among the initial 3621 participants with thyroid ultrasonography, 3218 (88.9\%) had complete data for TSH, $\mathrm{fT}_{4}$, urinary iodine and thiocyanate concentrations at baseline. Thyroid nodule, hyper- or hypoechogenic pattern, diffuse goiter and documented thyroid surgical therapy were the most frequent causes for exclusion in the reference population (Figure 1). Altogether, 880 subjects, 241 males and 639 females, who had at least one (previously known or unknown) thyroid disorder were excluded.

Thus, the disease-free population consisted of 2338 subjects $(72.7 \%$ of the initial sample): 1025 males $(81.0 \%$ ) aged (mean \pm SD) $52.0 \pm 4.8$ years, 571 females $(75.1 \%)$ aged between 35 and 44 years with a mean age of $40.5 \pm 2.8$, and 742 females $(62.2 \%)$ aged between 45 and 60 years with a mean age of $50.9 \pm 4.4$. Within each group, the social and demographic characteristics were comparable to those in the initial sample (Table 1). In this sample, $82.4 \%$ of males, $54.6 \%$ of females aged $35-44$ years, and $65.4 \%$ of females aged 45-60 years consumed alcoholic beverages, with mean alcohol intakes of $25.7 \pm 19.2$, $6.8 \pm 8.7$ and $9.4 \pm 10.3 \mathrm{~g}$, respectively. One-quarter of the participants $(26.5 \%)$ had 15 years or more of education, and $14.2 \%$ of the subjects currently smoked. Smoking was lower in the selected male group than in the total population ( $p=0.07)$.

In the disease-free population, thyroid volume was significantly higher in males than in females $(p<0.0001)$. The median and mean thyroid volume in the disease-free subgroups was smaller than the thyroid volume in the total population, and the upper limits for thyroid volume decreased sharply (Table 2). The median urinary iodine concentration was $<100 \mu \mathrm{g} / \mathrm{L}$ in all groups: $65.6 \%$ of males, $63.2 \%$ of $35-44$-year-old females and $62.7 \%$ of $45-60$-year-old females had urinary iodine concentrations $<100$ $\mu \mathrm{g} / \mathrm{L}$. They were similar to concentrations measured in the initial sample (Table 2).

\section{Concentration intervals for TSH and $\mathrm{fT}_{4}$}

In the disease-free population, the median TSH value (central 95\% range) was 1.63 (0.28-4.54) $\mathrm{mU} / \mathrm{L}$ in $45-60$-year-old males, $1.79(0.29-5.21) \mathrm{mU} / \mathrm{L}$ in 35-44-year-old females and $1.98(0.27-6.94) \mathrm{mU} / \mathrm{L}$ in 45-60-year-old females (Figure 2). Although the 2.5th percentile was comparable between the three groups, TSH median values increased significantly with age category in females $(p<0.0001)$. The upper limit of TSH was $5.21 \mathrm{mU} / \mathrm{L}$ in 35-44-year-old females, and increased by $33.2 \%$ for the $45-60$-year-old age group. Median TSH concentrations were higher in $45-60$-year-old females than in males $(p<0.0001)$, and the TSH upper limit for females aged $45-60$ years was $52.9 \%$ higher compared to males of the same age group (Figure 2).

Approximately one-fifth $(20.8 \%)$ of the males, onefourth $(27.2 \%)$ of the younger females and one-third $(33.9 \%)$ of the older females in our population had TSH values $>2.5 \mathrm{mU} / \mathrm{L}$ (Table 2). The corresponding percentages for $\mathrm{TSH}>4.5 \mathrm{mU} / \mathrm{L}$ were $2.8 \%, 5.4 \%$ and $7.7 \%$, respectively. Frequencies were slightly higher in female than in male subjects; in females, the percentages increased with age $(p<0.0001$ within gender and age groups). The corresponding figures for TSH $<0.2 \mathrm{mU} / \mathrm{L}$ were $1.7 \%, 0.9 \%$ and $1.1 \%$, respectively (Table 2).

A decrease in variation around the median TSH was observed between the initial sample and the diseasefree sample (Table 2). While the spreads of values for TSH were $4.57,5.62$, and $7.65 \mathrm{mU} / \mathrm{L}$ for the total population, the corresponding spreads for the selected groups were 4.54, 5.21, and $6.94 \mathrm{mU} / \mathrm{L}$. The TSH upper limits were slightly lower in the subsample than in the total population (Table 2).

The $\mathrm{fT}_{4}$ range was estimated in 2224 subjects $(975$ males aged 45-60 years, 544 females aged $35-44$ years and 705 females aged $45-60$ years) with TSH concentrations between the 2.5th and 97.5th percentiles. The $\mathrm{fT}_{4}$ median value (central 95\% range) was $10.7(7.85-13.60) \mathrm{ng} / \mathrm{L}$ for males, 11.0 


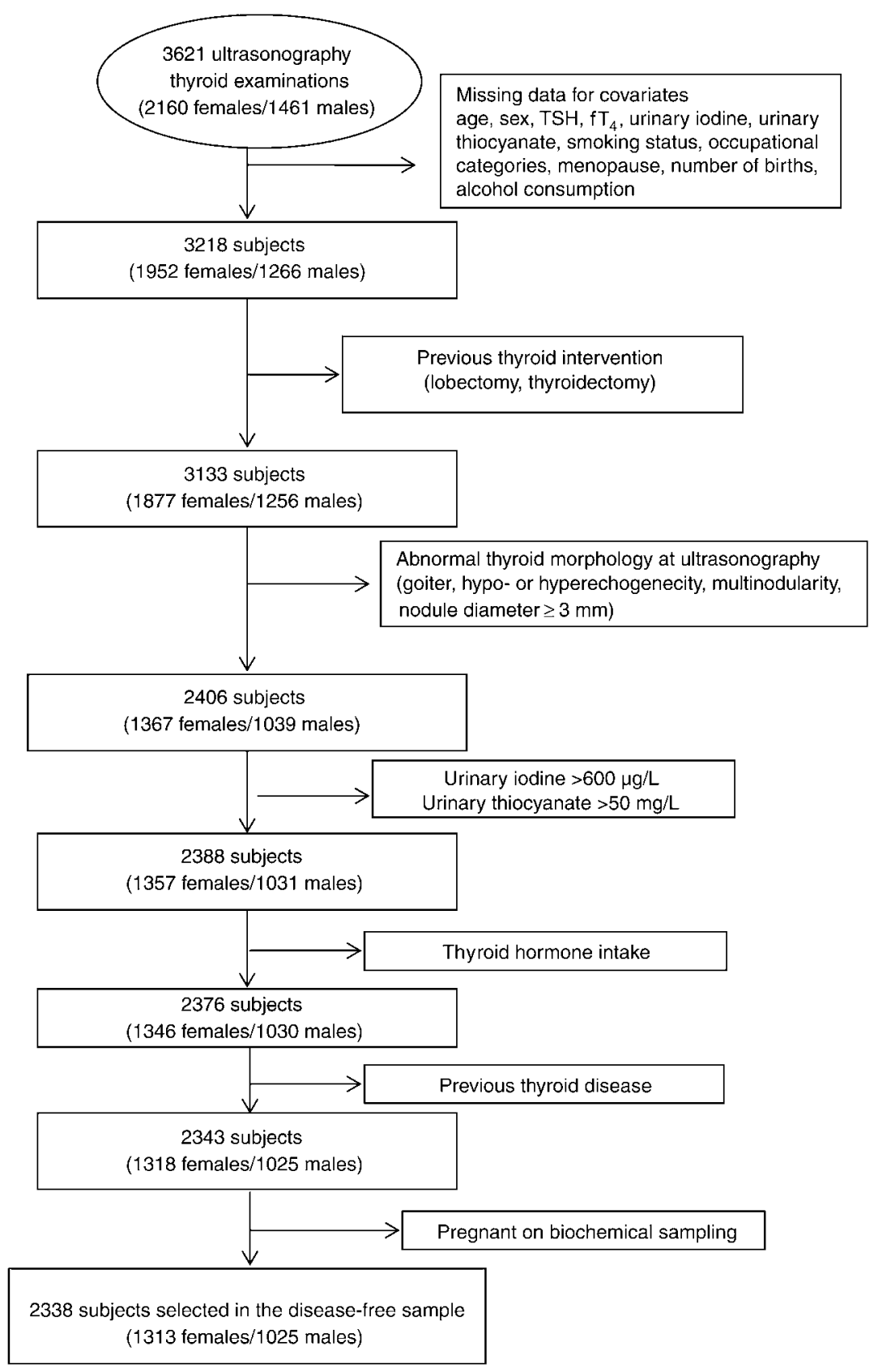

Figure 1 Selection of the disease-free sample (SU.VI.MAX Study 1994-1996).

(7.85-14.90) ng/L for females aged $35-44$ years and $10.9(8.20-13.65) \mathrm{ng} / \mathrm{L}$ for females aged $45-60$ years (Figure 3 ). The difference was statistically significant between males aged 45-60 years and females $(p<0.001)$. The mean $\mathrm{fT}_{4}$ concentrations were comparable between females aged $45-60$ years compared with those aged $35-44$ years $(p=0.08)$ and between males and females aged 45-60-year-old $(p=0.06)$ (Figure 3). The mean $\mathrm{fT}_{4}$ concentration was unchanged between the initial sample and the disease free sample (Table 2).

\section{Discussion}

In our study, ranges for $\mathrm{TSH}$ and $\mathrm{fT}_{4}$ were derived from a disease-free sample of French middle-aged adults. All participants had normal thyroid ultrasonography and strict exclusion criteria, with the exception of TPOAb measurements. The distribution of TSH differed significantly between males and females from the same age category, and in females according to age group. Mean $\mathrm{fT}_{4}$ and range intervals, estimated in subjects with TSH within the normal range, were comparable across age groups in females. However, there were differences between 45-60-yearold males and females. In our study, exclusion of at-risk individuals increased the lower bounds of the $95 \% \mathrm{TSH}$ limit, but had no effect on the mean and upper range $\mathrm{fT}_{4}$ concentrations in groups according to gender and age. In addition, the prevalence of mild hypothyroidism (TSH $>4.5 \mathrm{mU} / \mathrm{L}$ ) was approximately three-fold more common in females than males, consistent with earlier studies $(11,24)$. 


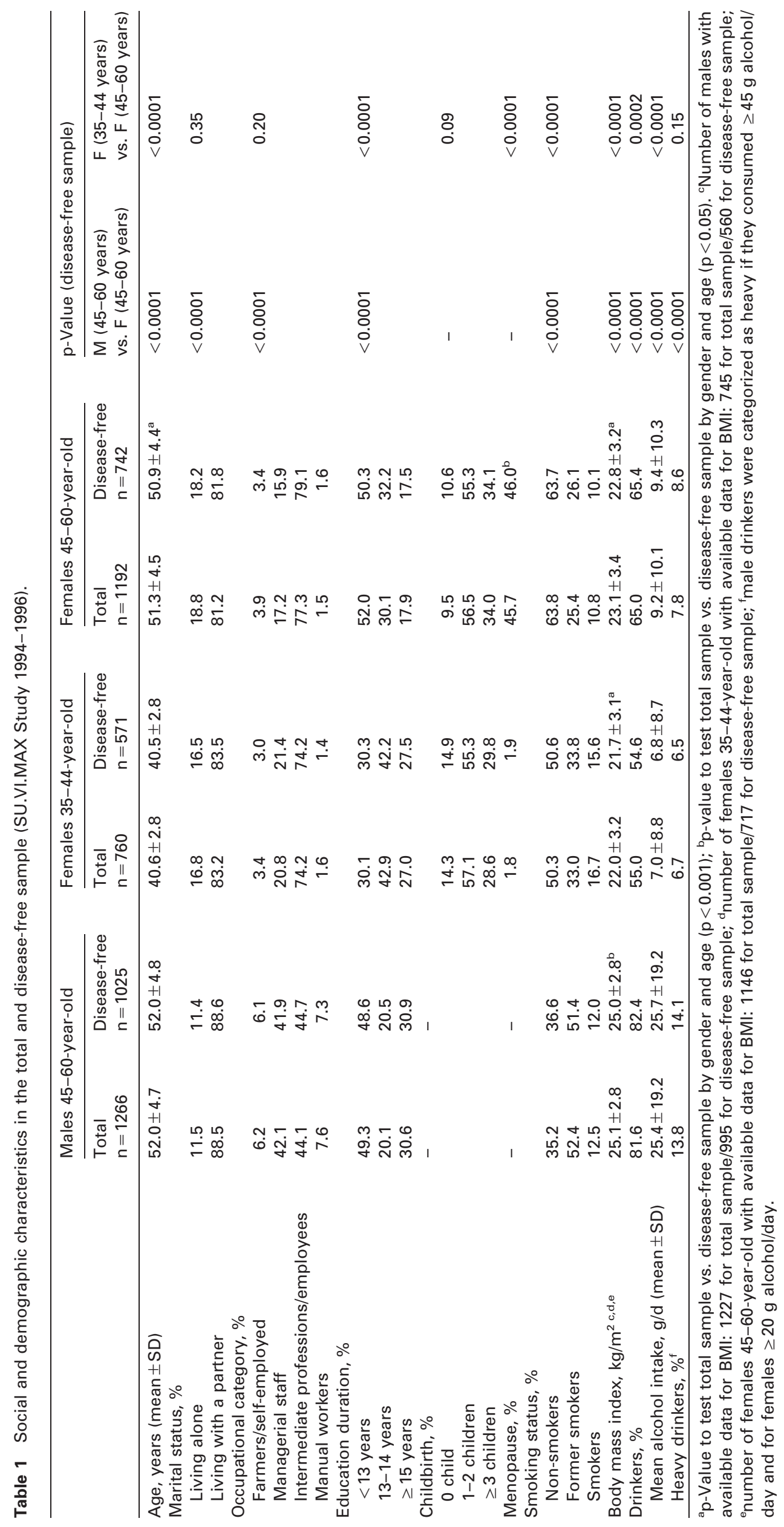




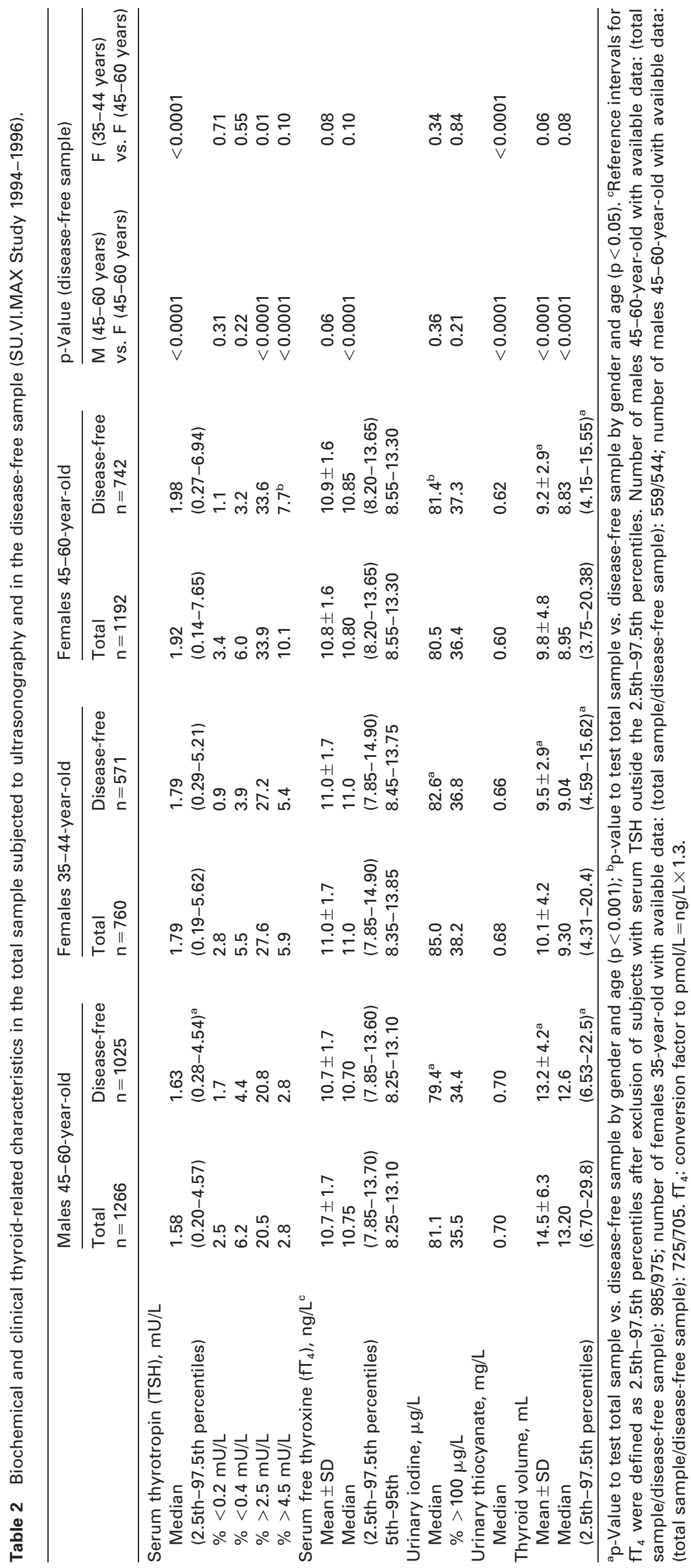




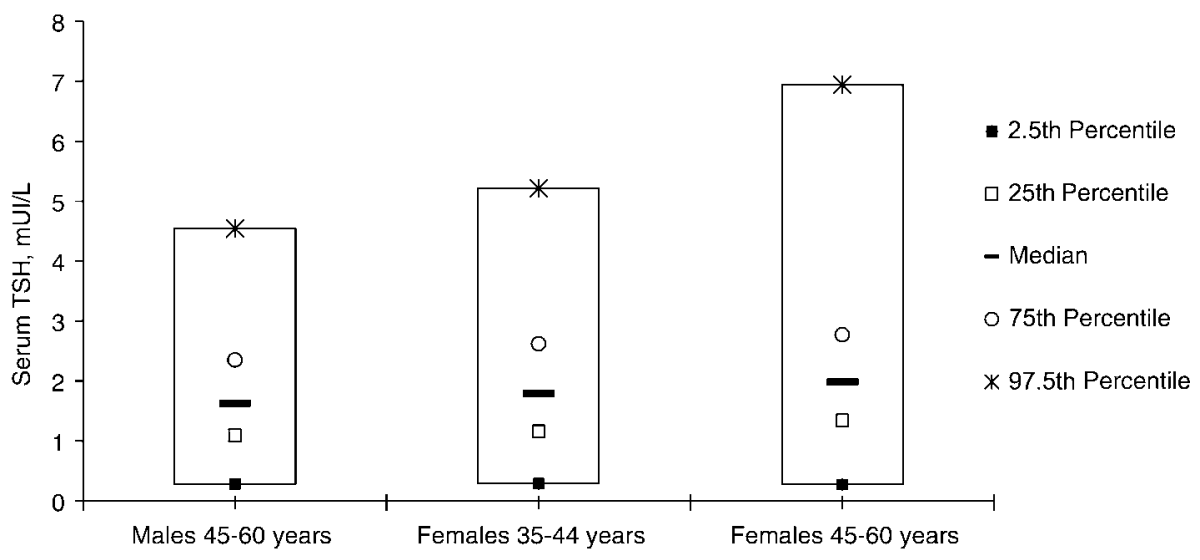

Figure 2 Serum TSH level (mUl/L) distribution by gender and age groups.

Most studies established one reference interval for a population, as recommended by the NACB (8). With our data, serum TSH concentrations were significantly affected by both age and gender, as reported in previous studies $(10,11,13)$. With respect to age, conflicting data have been reported. A trend toward higher serum TSH concentrations in older females was in agreement with the age related shift in the upper reference limits for serum TSH $(14,25)$. However, other studies reported a decline with age for serum TSH $(10,12,26)$. With gender, there were clear signs of an upward shift for both the mean and the upper $95 \%$ limit of the TSH range in females compared with males. Previous descriptions of benign thyroid diseases in the SU.VI.MAX cohort $(27,28)$ confirmed that the thyroid is exposed to a goiter effect due to iodine deficiency. In our study, age related changes in TSH concentrations may reflect physiological ageing of the thyroid as well as the iodine supply.

A recent NACB report suggested lowering the TSH upper limit reference value from 4.5 to $2.5 \mathrm{mU} / \mathrm{L}$ (8). This suggestion raised a storm of controversy (29-31). Despite the fact that examination of individuals was not based on NACB guidelines, which was not published when data were collected for our study, our interval limits can be assumed to be correct for middle-aged French adults. In fact, we found an upper limit of $\sim 4.0 \mathrm{mU} / \mathrm{L}$; this value is close to the upper limit determined in studies using NACB guidelines $(11,14,24,26,32-35)$.

A potential limiting factor of this study is that thyroid antibodies were not available. Therefore, some individuals with occult thyroid dysfunction were included in the calculated reference intervals (36). In fact, autoimmune thyroid disease is very common in this population (37), and individuals assumed to be disease free may have been contaminated by earlier occult autoimmune thyroid disease not detected by ultrasonography. However, several recent studies of thyroid-disease-free individuals found no significant change in the TSH upper limit in patients with antithyroid antibodies $(14,35,38)$. In addition, thyroid hypoechogenicity, a criterion used in our study, is considered a reliable tool for identifying chronic autoimmune disease (39). Also, it is considered to be an early marker of hypothyroidism in apparently healthy subjects (40).

Another potential limitation was the use of an older TSH assay which was considered acceptable when this study was initiated. Single biochemical measurements did not allow us to account for intraindividual variability (41). However, pre-analytical and analytical sources of variation were minimized through strict standard operating procedures.

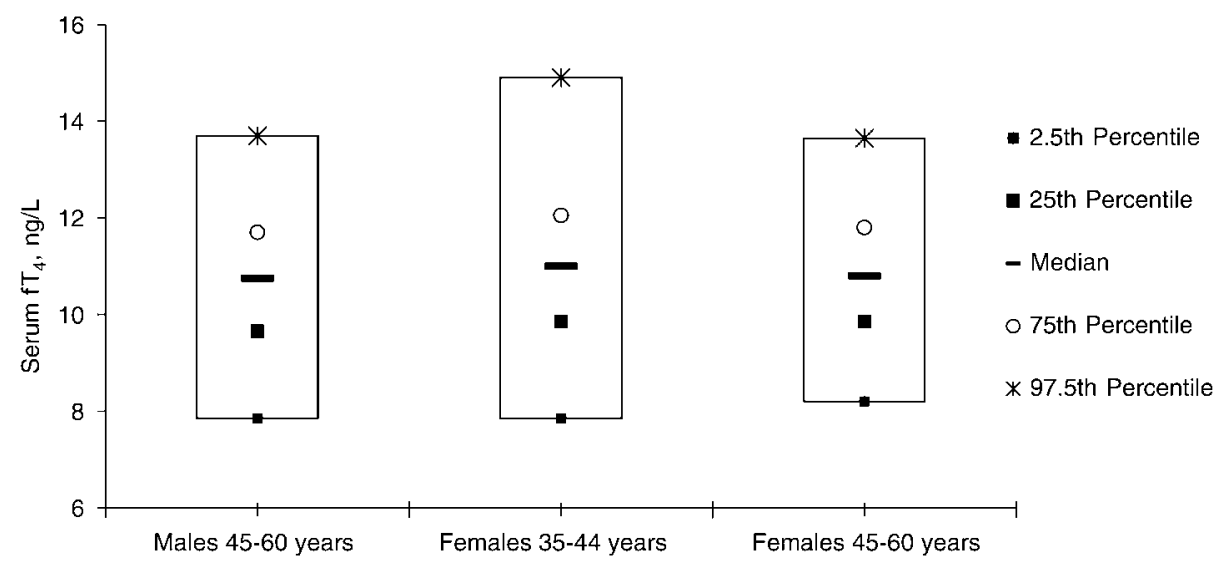

Figure 3 Serum $\mathrm{fT}_{4}$ level (ng/L) distribution by gender and age groups (after exclusion of participants with TSH outside the 2.5th and 97.5th percentiles (reference interval). Conversion factor to $\mathrm{pmol} / \mathrm{L}=\mathrm{ng} / \mathrm{L} \times 1.3$. 
The SU.VI.MAX study provided a unique opportunity to characterize abnormal thyroid function in two subsets of the SU.VI.MAX cohort. An initial evaluation of abnormal TSH values based on serum samples from apparently healthy subjects has already been published (42). As mentioned previously, since examinations of individuals was not based on NACB guidelines, we took the opportunity to focus on the ultrasonography subsample to define TSH and $\mathrm{fT}_{4}$ ranges in a disease-free population.

The strengths of our study lie in the relatively large number of well-defined subjects, and a selection procedure which excluded important confounding factors. In addition, clinical or biological thyroid dysfunction was not included in the initial exclusion criteria for participation in the SU.VI.MAX trial (19), making selection bias very unlikely. In addition, ultrasonographic thyroid examinations were performed on a random subsample of the SU.VI.MAX cohort prior to completion of TSH and $\mathrm{fT}_{4}$ assays. Although not a criterion in the NACB recommendations for defining a healthy population (8), thyroid ultrasonography may be an important parameter since TSH standards differed according to whether ultrasonography was or was not taken into consideration $(12,14)$.

Decreasing the reference limits would classify three to four times more subjects as having hypothyroidism $(29,34)$. In our population, decreasing the upper limit of the TSH interval would dramatically increase (by up to $26 \%$ ) the diagnosis of biochemical hypothyroidism. This would lead to supplementary medical expenses; already high in France $(2,3)$. In addition, decreasing the TSH upper limit of the reference range from 4.5 to $2.5 \mathrm{mU} / \mathrm{L}$ (8) would result in potentially unnecessary levothyroxine replacement therapy for many patients for whom there is no demonstrated therapeutic benefit (29). Further studies should determine whether variations due to gender, and to age in females, are clinically relevant in order to validate the advantage of using separate reference values.

Several studies have provided evidence that TSH in the upper reference range is often associated with primary cardiovascular risk factors in susceptible individuals (43). Early treatment would prevent progression to subnormal values, but the balance between benefits and harm is unclear. Large randomized trial studies are required to evaluate the potential benefit of thyroid hormone therapy for metabolic parameters and quality of life.

\section{Conflict of interest statement}

All authors declared: not having accepted any funding or support from an organization that may in any way gain or lose financially from the results of our study; not having been employed by an organization that may in any way gain or lose financially from the results of our study; not having any other conflicting interests.

\section{Acknowledgements}

This study was supported by grants from Lipha-Santé, the Ministry of Health (DGS) and the Institut de Veille Sanitaire.

\section{References}

1. Canaris GJ, Manowitz NR, Mayor G, Ridgway EC. The Colorado thyroid disease prevalence study. Arch Intern Med 2000;160:526-34.

2. Caisse Nationale d'Assurance Maladie des Travailleurs Salariés (CNAMTS). Les actes de biologie remboursés en 2005 et 2006 par le régime général d'assurance maladie. http://www.ameli.fr/fileadmin/user_upload/documents/ Biolam_2004-2005-2006_ameli.xls. Accessed August 10, 2009.

3. Caisse Nationale d'Assurance Maladie des Travailleurs Salariés (CNAMTS). Médicaments remboursables par le Régime Général au cours des années 2002 à 2007. http://www.ameli.fr/l-assurance-maladie/statistiques-etpublications/donnees-statistiques/medic-am-generic-ambiolam-Ipp-am/medic-am-2002-2007 - edition-avril-2008. php. Accessed August 10, 2009.

4. Toft AD, Beckett GF. Measuring serum thyrotropin and thyroid hormone and assessing thyroid hormone transport. In: Braverman LE, Utiger R. Werner \& Ingbar's. The thyroid: a fundamental and clinical text. Philadelphia: Lippincott Williams \& Wilkins, 2005:329-44.

5. Cappola AR, Fried LP, Arnold AM, Danese MD, Kuller LH, Burke GL, et al. Thyroid status, cardiovascular risk, and mortality in older adults. J Am Med Assoc 2006;295: 1033-41.

6. Gharib H, Tuttle RM, Baskin HJ, Fish LH, Singer PA, McDermott MT. Subclinical thyroid dysfunction: a joint statement on management from the American Association of Clinical Endocrinologists, the American Thyroid Association, and the Endocrine Society. J Clin Endocrinol Metab 2005;90:581-5.

7. Hay ID, Bayer MF, Kaplan MM, Klee GG, Larsen PR, Spencer CA. American Thyroid Association assessment of current free thyroid hormone and thyrotropin measurements and guidelines for future clinical assays. The Committee on Nomenclature of the American Thyroid Association. Clin Chem 1991;37:2002-8.

8. Baloch Z, Carayon P, Conte-Devolx B, Demers LM, FeldtRasmussen U, Henry JF, et al. Laboratory medicine practice guidelines. Laboratory support for the diagnosis and monitoring of thyroid disease. Thyroid 2003;13:3-126.

9. Tunbridge WM, Evered DC, Hall R, Appleton D, Brewis $\mathrm{M}$, Clark $\mathrm{F}$, et al. The spectrum of thyroid disease in a community: the Whickham survey. Clin Endocrinol (Oxf) 1977;7:481-93.

10. Knudsen N, Bulow I, Jorgensen T, Laurberg P, Ovesen $\mathrm{L}$, Perrild $\mathrm{H}$. Comparative study of thyroid function and types of thyroid dysfunction in two areas in Denmark with slightly different iodine status. Eur J Endocrinol 2000;143:485-91.

11. Hollowell JG, Staehling NW, Flanders WD, Hannon WH, Gunter EW, Spencer CA, et al. Serum TSH, T(4), and thyroid antibodies in the United States population (1988 to 1994): National Health and Nutrition Examination Survey (NHANES III). J Clin Endocrinol Metab 2002;87:489-99.

12. Volzke $H$, Alte $D$, Kohlmann T, Ludemann J, Nauck M, John U, et al. Reference intervals of serum thyroid function tests in a previously iodine-deficient area. Thyroid 2005;15:279-85.

13. Gonzalez-Sagrado M, Martin-Gil FJ. Population-specific reference values for thyroid hormones on the Abbott ARCHITECT i2000 analyzer. Clin Chem Lab Med 2004;42: 540-2.

14. Kratzsch J, Fiedler GM, Leichtle A, Brugel M, Buchbinder $S$, Otto $L$, et al. New reference intervals for thyrotropin and thyroid hormones based on National Academy of Clinical Biochemistry criteria and regular ultrasonography of the thyroid. Clin Chem 2005;51:1480-6. 
15. Nyrnes A, Jorde R, Sundsfjord J. Serum TSH is positively associated with BMI. Int J Obes (Lond) 2006;30:100-5.

16. Valeix $P$, Faure $P$, Bertrais $S$, Vergnaud AC, Dauchet $L$, Hercberg S. Effects of light to moderate alcohol consumption on thyroid volume and thyroid function. Clin Endocrinol (Oxf) 2008;68:988-95.

17. Belin RM, Astor BC, Powe NR, Ladenson PW. Smoke exposure is associated with a lower prevalence of serum thyroid autoantibodies and thyrotropin concentration elevation and a higher prevalence of mild thyrotropin concentration suppression in the third National Health and Nutrition Examination Survey (NHANES III). J Clin Endocrinol Metab 2004;89:6077-86.

18. Jensen E, Blaabjerg O, Petersen PH, Hegedus L. Sampling time is important but may be overlooked in establishment and use of thyroid-stimulating hormone reference intervals. Clin Chem 2007;53:355-6.

19. Hercberg S, Galan P, Preziosi P, Bertrais S, Mennen L, Malvy D, et al. The SU.VI.MAX Study: a randomized, placebo-controlled trial of the health effects of antioxidant vitamins and minerals. Arch Intern Med 2004;164:233542.

20. Lasfargues G, Vol S, Le Clesiau H, Bedouet M, Hagel L, Constans $\mathrm{T}$, et al. [Validity of a short self-administered dietary questionnaire compared with a dietetic interview]. Presse Med 1990;19:953-7.

21. Brunn J, Block U, Ruf G, Bos I, Kunze WP, Scriba PC. [Volumetric analysis of thyroid lobes by real-time ultrasound (author's transl)]. Dtsch Med Wochenschr 1981; 106:1338-40.

22. Berghout A, Wiersinga WM, Smits NJ, Touber JL. Determinants of thyroid volume as measured by ultrasonography in healthy adults in a non-iodine deficient area. Clin Endocrinol (Oxf) 1987;26:273-80.

23. Gutekunst R, Becker W, Hehrmann R, Olbricht T, Pfannenstiel P. [Ultrasonic diagnosis of the thyroid gland]. Dtsch Med Wochenschr 1988;113:1109-12.

24. O'Leary PC, Feddema PH, Michelangeli VP, Leedman PJ, Chew GT, Knuiman M, et al. Investigations of thyroid hormones and antibodies based on a community health survey: the Busselton thyroid study. Clin Endocrinol (Oxf) 2006;64:97-104.

25. Surks MI, Hollowell JG. Age-specific distribution of serum thyrotropin and antithyroid antibodies in the US population: implications for the prevalence of subclinical hypothyroidism. J Clin Endocrinol Metab 2007;92:457582.

26. Hoogendoorn $E H$, Hermus AR, de Vegt $F$, Ross $H A$, Verbeek AL, Kiemeney LA, et al. Thyroid function and prevalence of anti-thyroperoxidase antibodies in a population with borderline sufficient iodine intake: influences of age and sex. Clin Chem 2006;52:104-11.

27. Valeix P, Zarebska M, Preziosi P, Galan P, Pelletier B, Hercberg S. lodine deficiency in France. Lancet 1999;353: 1766-7.

28. Barrere $X$, Valeix $P$, Preziosi $P$, Bensimon $M$, Pelletier B, Galan $P$, et al. Determinants of thyroid volume in healthy French adults participating in the SU.VI.MAX cohort. Clin Endocrinol (Oxf) 2000;52:273-8.

29. Fatourechi V, Klee GG, Grebe SK, Bahn RS, Brennan MD,
Hay ID, et al. Effects of reducing the upper limit of normal TSH values. J Am Med Assoc 2003;290:3195-6.

30. Wartofsky L, Dickey RA. The evidence for a narrower thyrotropin reference range is compelling. $\mathrm{J}$ Clin Endocrinol Metab 2005;90:5483-8.

31. Brabant G, Beck-Peccoz P, Jarzab B, Laurberg P, Orgiazzi $\mathrm{J}$, Szabolcs I, et al. Is there a need to redefine the upper normal limit of TSH? Eur J Endocrinol 2006;154:633-7.

32. Jensen E, Hyltoft PP, Blaabjerg O, Hansen PS, Brix TH, Kyvik KO, et al. Establishment of a serum thyroid stimulating hormone (TSH) reference interval in healthy adults. The importance of environmental factors, including thyroid antibodies. Clin Chem Lab Med 2004;42:82432.

33. d'Herbomez M, Jarrige V, Darte C. Reference intervals for serum thyrotropin (TSH) and free thyroxine (FT4) in adults using the Access Immunoassay System. Clin Chem Lab Med 2005;43:102-5.

34. Surks MI, Goswami G, Daniels GH. The thyrotropin reference range should remain unchanged. J Clin Endocrinol Metab 2005;90:5489-96.

35. Hamilton TE, Davis S, Onstad L, Kopecky KJ. Thyrotropin levels in a population with no clinical, autoantibody, or ultrasonographic evidence of thyroid disease: implications for the diagnosis of subclinical hypothyroidism. J Clin Endocrinol Metab 2008:93:1224-30.

36. Spencer CA, Hollowell JG, Kazarosyan M, Braverman LE. National Health and Nutrition Examination Survey III thyroid-stimulating hormone (TSH)-thyroperoxidase antibody relationships demonstrate that TSH upper reference limits may be skewed by occult thyroid dysfunction. J Clin Endocrinol Metab 2007;92:4236-40.

37. Dayan CM, Daniels GH. Chronic autoimmune thyroiditis. N Engl J Med 1996;335:99-107.

38. Eskelinen S, Suominen P, Vahlberg T, Lopponen M, Isoaho R, Kivela SL, et al. The effect of thyroid antibody positivity on reference intervals for thyroid stimulating hormone (TSH) and free thyroxine (FT4) in an aged population. Clin Chem Lab Med 2005;43:1380-5.

39. Rago T, Chiovato L, Grasso L, Pinchera A, Vitti P. Thyroid ultrasonography as a tool for detecting thyroid autoimmune diseases and predicting thyroid dysfunction in apparently healthy subjects. J Endocrinol Invest 2001;24: 763-9.

40. Vejbjerg $P$, Knudsen $N$, Perrild $H$, Laurberg $P$, Pedersen IB, Rasmussen LB, et al. The association between hypoechogenicity or irregular echo pattern at thyroid ultrasonography and thyroid function in the general population. Eur J Endocrinol 2006;155:547-52.

41. Andersen S, Bruun NH, Pedersen KM, Laurberg P. Biologic variation is important for interpretation of thyroid function tests. Thyroid 2003;13:1069-78.

42. Valeix P, Dos Santos C, Castetbon K, Bertrais S, Cousty C, Hercberg S. Statut thyroïdien et fréquences des dysthyroïdies chez les adultes inclus dans l'étude SU.VI.MAX en 1994-1995. Ann Endocrinol (Paris) 2004; 65:477-86.

43. Ochs N, Auer R, Bauer DC, Nanchen D, Gussekloo J, Cornuz J, et al. Meta-analysis: subclinical thyroid dysfunction and the risk for coronary heart disease and mortality. Ann Intern Med 2008;148:832-45. 